\title{
Phosphonium ionic liquids as extractants for recovery of ruthenium(III) from acidic aqueous solutions
}

\author{
Martyna Rzelewska $^{1}$ - Monika Baczyńska ${ }^{1}$ Maciej Wiśniewski ${ }^{1} \cdot$ \\ Magdalena Regel-Rosocka ${ }^{1}$ (B)
}

Received: 6 July 2016/Accepted: 24 November 2016/Published online: 21 December 2016

(C) The Author(s) 2016. This article is published with open access at Springerlink.com

\begin{abstract}
The aim of this work is to investigate extraction of ruthenium(III) from acidic aqueous solutions with phosphonium ionic liquids such as trihexyl(tetradecyl)phosphonium chloride (Cyphos IL 101), trihexyl(tetradecyl)phosphonium bis(2,4,4-trimethylpentyl)phosphinate (Cyphos IL 104) and tributyl(tetradecyl)phosphonium chloride (Cyphos IL 167) as extractants. The influence of $\mathrm{HCl}$ content in the feed solutions on extraction of $\mathrm{Ru}(\mathrm{III})$ was investigated. The research was performed for model solutions containing $\mathrm{Ru}(\mathrm{III})$ and a mixture of waste solutions containing $\mathrm{Ru}(\mathrm{III})$ and $\mathrm{Rh}(\mathrm{III})$. In addition, investigation of the type of extractant and its concentration in the organic phase on extraction of $\mathrm{Ru}(\mathrm{III})$ was carried out. Co-extraction of protons to the organic phase was determined. To the best of our knowledge, the extraction of $\mathrm{Ru}(\mathrm{III})$ with Cyphos IL 167 (tributyl(tetradecyl)phosphonium chloride) as an extractant has not yet been described in the scientific literature.
\end{abstract}

Keywords Liquid-liquid extraction · Ruthenium(III) · Rhodium(III) · Phosphonium ionic liquid · Cyphos IL 101 . Cyphos IL $104 \cdot$ Cyphos IL 167

Presented at the 43rd International Conference of Slovak Society of Chemical Engineering held in Tatranské Matliare on May 23-27, 2016.

Magdalena Regel-Rosocka

magdalena.regel-rosocka@ put.poznan.pl

1 Faculty of Chemical Technology, Institute of Chemical Technology and Engineering, Poznan University of Technology, ul. Berdychowo 4, 60-965 Poznan, Poland

\section{Introduction}

The Platinum Group Metals (PGM) such as rhodium, ruthenium, palladium and platinum are extremely rare in nature comparing to other metals. Natural ores contain small amounts of PGM; therefore, their cost of production is very high. All over the world, PGM are mined mainly in South Africa (The Bushveld Complex), Russia (The Urals deposits), North America (Canada) and Zimbabwe (The Great Dyke) (Matthey 2016). The technological process of platinum ore processing is energy-consuming and also causes environment-damaging activities. On a global scale, $31 \%$ production of $\mathrm{Pt}, 57 \%$ production of $\mathrm{Pd}$ and $84 \%$ production of $\mathrm{Rh}$ are used to produce automotive catalytic converters. Currently, secondary sources such as waste electrical and electronic equipment and catalytic converters become the main source of PGM (Fornalczyk and Saternus 2007).

Due to the large interest in these metals, new methods of PGM recovery are developed. A popular processing of PGM from the secondary sources covers leaching and reactive extraction. At first, waste material, mainly spent petroleum and automotive catalysts containing PGM and non-precious metals such as $\mathrm{Cu}, \mathrm{Fe}, \mathrm{Mg}, \mathrm{Ca}, \mathrm{Zn}$ and $\mathrm{Bi}$, is leached with concentrated hydrochloric acid (Dragulovic et al. 2011; Pośpiech 2012; Sun and Lee 2013). After leaching, a pregnant leach solution (PLS) with desirable ion metals is contacted with organic phase containing an extractant to recover valuable metals from PLS.

A reactive extraction is a simple and efficient technique for separation of metal ions from diluted effluents. In addition, the reactive extraction is the most popular separation technique of metal ions among hydrometallurgical methods but the use of organic compounds (many times volatile organic compounds) is indicated as its drawback. 
For over 15 years, ionic liquids (ILs) have been established as popular and efficient extractants or solvents in separation processes (Abbott et al. 2011; Billard, 2013; Regel-Rosocka and Materna 2014). Ionic liquids, such as phosphonium ILs, can be used as extractants for liquidliquid extraction of organic compounds (Marták and Schlosser 2004, 2006, 2016), lanthanides (Kumari et al. 2016), heavy metals (Guo et al. 2011; Leyma et al. 2016; Regel-Rosocka et al. 2006, 2012; Vander Hoogerstraete et al. 2013) or PGMs (Cieszynska and Wisniewski 2010, 2012; Papaiconomou et al. 2015; Regel-Rosocka et al. 2015; Rzelewska et al. 2016). They are also applied as carriers of metal ions in polymer inclusion membranes (Baczyńska et al. 2016; Baczyńska and Regel-Rosocka 2013; Kogelnig et al. 2011; Pośpiech 2015; Regel-Rosocka et al. 2012, 2015) or supported liquid membranes (Alguacil et al. 2010; de San et al. 2014) and in sorption as Cyphosimpregnated resins or biopolymer capsules (Guibal et al. 2008; Navarro et al. 2016; Vincent et al. 2008).

The main interest in PGM extraction is focused on the separation of $\mathrm{Pd}(\mathrm{II})$ and $\mathrm{Pt}(\mathrm{IV})$ from $\mathrm{HCl}$ solutions (Cieszyńska and Wiśniewski 2010, 2012; Papaiconomou et al. 2015), while extraction systems for $\mathrm{Ru}(\mathrm{III})$ and $\mathrm{Rh}$ (III) separation are scarcely described. Selective extraction of $\mathrm{Ru}(\mathrm{III})$ in the presence of $\mathrm{Ir}(\mathrm{IV}$ ) and $\mathrm{Rh}$ (III) (Góralska et al. 2007) with Alamine 336 or in the presence of Os(IV) and $\mathrm{Pt}(\mathrm{IV})$ with thiourea derivative (Kuchekar et al. 2015) was studied. In addition, an analytical application of 4-pyridone derivatives for $\mathrm{Ru}(\mathrm{III})$ extraction from large amounts of $\mathrm{Pd}(\mathrm{II})$ and $\mathrm{Rh}(\mathrm{III})$ was proposed (Druškovic et al. 2005).

Looking for selective extractants to separate $\mathrm{Ru}(\mathrm{III})$ from $\mathrm{Rh}(\mathrm{III})$ the authors of the paper propose to use phosphonium ILs. The problem of separation of these metal ions is important because of scarce natural ores and increasing demand for them. The aim of this work is to investigate the effect of $\mathrm{HCl}$ content in the feed on extraction of ruthenium(III) from acidic aqueous solutions with phosphonium ionic liquids such as trihexyl(tetradecyl)phosphonium chloride (Cyphos IL 101), trihexyl(tetradecyl)phosphonium bis(2,4,4trimethylpentyl)phosphinate (Cyphos IL 104) and tributyl(tetradecyl)phosphonium chloride (Cyphos IL 167) as extractants. It is important to mention that also selective extraction of $\mathrm{Ru}(\mathrm{III})$ in the presence of $\mathrm{Rh}(\mathrm{III})$ was investigated.

\section{Experimental}

\section{Chemicals}

Phosphonium ionic liquids, trihexyl(tetradecyl)phosphonium chloride (Cyphos IL 101), trihexyl(tetradecyl)phosphonium bis(2,4,4-trimethylpentyl)phosphinate (Cyphos IL 104) and tributyl(tetradecyl)phosphonium chloride (Cyphos IL 167) supplied by Cytec Industries Inc., were dissolved in toluene $\left(5 \times 10^{-3}, 2 \times 10^{-2}\right.$ and $\left.5 \times 10^{-2} \mathrm{M}\right)$. The structures of the ILs applied are presented in Table 1 .

A twofold excess of phosphonium IL in the organic phase to $\mathrm{Ru}(\mathrm{III})$ content in the feed was taken into consideration in all the presented extraction studies. The model aqueous solutions contained $2.5 \times 10^{-3} \mathrm{M} \mathrm{Ru}$ (III) in 0.1 , 1,3 and $5 \mathrm{M} \mathrm{HCl}$. Another feed solution contained mixture of $\mathrm{Ru}(\mathrm{III})$ and $\mathrm{Rh}(\mathrm{III})$ containing $1.7 \times 10^{-3} \mathrm{M} \mathrm{Ru}(\mathrm{III})$ and $0.5 \times 10^{-3} \mathrm{M} \mathrm{Rh}(\mathrm{III})$ in $2.5 \mathrm{M} \mathrm{HCl}$ with $2.9 \mathrm{M} \mathrm{NaCl}$. In addition, an effect of IL concentration in the organic phase on extraction of metal ions was studied.

\section{Methods and analytical equipment}

Extraction was carried out in glass separatory funnels for $20 \mathrm{~min}$ at $22 \pm 2{ }^{\circ} \mathrm{C}$. Feed solutions containing $2.5 \times 10^{-3} \mathrm{M} \mathrm{Ru}(\mathrm{III})$ in various concentrations of $\mathrm{HCl}$ or mixture of: $1.7 \times 10^{-3} \mathrm{M} \mathrm{Ru}(\mathrm{III})$ and $0.5 \times 10^{-3} \mathrm{M}$ $\mathrm{Rh}$ (III) in $2.5 \mathrm{M} \mathrm{HCl}$ with $2.9 \mathrm{M} \mathrm{NaCl}$ were mechanically shaken with IL-containing phase (volume ratio w/o $=1$ ) and then allowed to stand for phase separation. Stripping of $\mathrm{Ru}$ (III) ions from the loaded organic phases was carried out with $0.1 \mathrm{M}$ thiourea in $0.5 \mathrm{M} \mathrm{HCl}$. The loaded organic phase and the stripping phase were shaken at volume ratio $\mathrm{w} / \mathrm{o}=1$ for $20 \mathrm{~min}$ at $22 \pm 2{ }^{\circ} \mathrm{C}$ in glass separatory funnels and then allowed to stand for phase separation. Atomic absorption spectrometer Hitachi Z-8200 was used for determination of $\mathrm{Rh}(\mathrm{III})$ and $\mathrm{Ru}(\mathrm{III})$ in the aqueous solutions at 369.2 and $349.9 \mathrm{~nm}$, respectively. $\mathrm{HCl}$ concentration in the aqueous phases was determined by potentiometric titration with $0.1 \mathrm{M} \mathrm{NaOH}$ (702 SM, Metrohm).

\section{Results and discussion}

\section{Influence of $\mathrm{HCl}$ concentration in $\mathrm{Ru}(\mathrm{III})$ extraction}

Effect of concentration of $\mathrm{HCl}$ in the feed solution on $\mathrm{Ru}(\mathrm{III})$ extraction was studied and the results are shown in Table 2. Both phases (the feed solution and the IL-containing organic phase) were shaken together for $20 \mathrm{~min}$. Distribution ratio $\mathrm{D}_{\mathrm{Ru}(\mathrm{III})}$ was defined as the ratio of $\mathrm{Ru}(\mathrm{III})$ concentrations in the organic $C^{*}{ }_{(\text {org) }}$ and the aqueous $C^{*}$ (aq) phases after extraction (IUPAC 2014).

The highest distribution ratio of $\mathrm{Ru}(\mathrm{III})$ is obtained for IL 167 as an extractant and reaches even more than 2.7 (for $1 \mathrm{M} \mathrm{HCl}$ in the feed). $\mathrm{D}_{\mathrm{Ru}(\mathrm{III})}$ values amount to $0.26-0.35$, and are the smallest for all ILs when the concentration of $\mathrm{HCl}$ in the feed solution is $5 \mathrm{M}$. The values presented in 
Table 1 Structures of the ILs
Cyphos IL 101
Cyphos IL 167

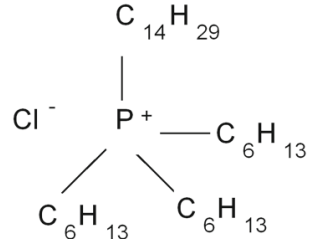

trihexyl(tetradecyl)phosphonium tributyl(tetradecyl)phosphonium chloride chloride

\section{Cyphos IL 104}

Table 2 Distribution ratio of $\mathrm{Ru}(\mathrm{III})$ between Cyphos IL 101, IL 104 or IL 167-containing organic phases and aqueous solutions with various concentrations of $\mathrm{HCl}$

\begin{tabular}{llll}
\hline HCl concentration/M & \multicolumn{3}{l}{$\mathbf{D}_{\text {Ru(III) }}$} \\
\cline { 2 - 4 } & Cyphos IL 101 & Cyphos IL 104 & Cyphos IL 167 \\
\hline 0.1 & $1.48 \pm 0.09$ & $1.44 \pm 0.09$ & $2.28 \pm 0.18$ \\
1 & $2.28 \pm 0.27$ & $2.10 \pm 0.27$ & $2.72 \pm 0.18$ \\
3 & $2.62 \pm 0.45$ & $1.65 \pm 0.18$ & $2.00 \pm 0.36$ \\
5 & $0.35 \pm 0.09$ & $0.26 \pm 0.00$ & $0.27 \pm 0.18$ \\
\hline (Organic phase: $5 \times 10^{-3} \mathrm{M}$ IL in toluene; feed phase: $2.5 \times 10^{-3} \mathrm{M} \mathrm{Ru(III)} \mathrm{in} \mathrm{0.1-5} \mathrm{M} \mathrm{HCl)}$
\end{tabular}

Table 2 indicate that Cyphos IL 167 extracts Ru(III) from low HCl-concentrated feeds much better than Cyphos IL 101 and IL 104. However, relatively short carbon chains at tributyl(tetradecyl)phosphonium cation make Cyphos IL 167 more hydrophilic than Cyphos IL 101. Hence, formation of emulsions and very slow and difficult phase separation are noted for this IL. The emulsions after extraction were left for $24 \mathrm{~h}$ to complete separation and to analyze $\mathrm{Ru}(\mathrm{III})$ and $\mathrm{Rh}(\mathrm{III})$ extraction. This is the reason for elimination of IL 167 from our studies in the future.

Increase in $\mathrm{HCl}$ concentration in the feed causes positive changes in $\mathrm{D}_{\mathrm{Ru}(\mathrm{III})}$ up to certain $\mathrm{HCl}$ content, after reaching maximum value of $D_{\mathrm{Ru}(\mathrm{III})}(2.62$ at $3 \mathrm{M} \mathrm{HCl}$ with Cyphos
IL 101 and 2.10; 2.72 at $1 \mathrm{M} \mathrm{HCl}$ for Cyphos IL 104 and IL 167, respectively) the distribution of $\mathrm{Ru}(\mathrm{III})$ into the organic and the aqueous phases decreases. This negative effect of $\mathrm{HCl}$ presence in the feed on efficiency of $\mathrm{Ru}$ (III) extraction is likely to be caused by co-extraction of the acid into the organic phase, which is particularly visible for the feed containing $5 \mathrm{M} \mathrm{HCl}$.

Therefore, concentration of hydrochloric acid before and after Ru(III) extraction was determined in the aqueous phases, and the results of $\mathrm{HCl}$ transport to the organic phase are shown in Table 3. Additionally, transport of the acid from the feeds without $\mathrm{Ru}(\mathrm{III})$ was studied and is shown also in Table 3. 
Table 3 Hydrochloric acid extraction to the organic phases of $5 \times 10^{-3}$ M Cyphos IL 101, Cyphos IL 104 or Cyphos IL 167

\begin{tabular}{|c|c|c|c|c|c|c|}
\hline \multirow[t]{2}{*}{$\mathrm{HCl} / \mathrm{M}$} & \multicolumn{2}{|c|}{ After extraction with IL 101} & \multicolumn{2}{|c|}{ After extraction with IL 104} & \multicolumn{2}{|c|}{ After extraction with IL 167} \\
\hline & $\mathrm{HCl}_{\mathrm{aq}} / \mathrm{M}$ & $\mathrm{HCl}_{\text {org }} / \mathrm{M}$ & $\mathrm{HCl}_{\mathrm{aq}} / \mathrm{M}$ & $\mathrm{HCl}_{\text {org }} / \mathrm{M}$ & $\mathrm{HCl}_{\mathrm{aq}} / \mathrm{M}$ & $\mathrm{HCl}_{\mathrm{org}} / \mathrm{M}$ \\
\hline \multicolumn{7}{|c|}{ Feed: $2.5 \times 10^{-3} \mathrm{M} \mathrm{Ru}(\mathrm{III})$ in $0.1-5 \mathrm{M} \mathrm{HCl}$} \\
\hline 0.1 & 0.094 & 0.004 & 0.096 & 0.002 & 0.097 & 0.012 \\
\hline 1 & 0.983 & 0.006 & 0.970 & 0.019 & 0.897 & 0.019 \\
\hline 3 & 2.767 & 0.042 & 2.751 & 0.050 & 2.640 & 0.067 \\
\hline 5 & 4.554 & 0.047 & 4.545 & 0.056 & 4.394 & 0.126 \\
\hline \multicolumn{7}{|c|}{ Feed: aqueous solutions of $0.1-5 \mathrm{M} \mathrm{HCl}$} \\
\hline 0.1 & 0.096 & 0.007 & 0.097 & 0.006 & 0.102 & 0.001 \\
\hline 1 & 0.942 & 0.005 & 0.945 & 0.002 & 0.928 & 0.016 \\
\hline 3 & 2.864 & 0.027 & 2.872 & 0.019 & 2.815 & 0.076 \\
\hline 5 & 4.919 & 0.291 & 5.008 & 0.202 & 4.877 & 0.334 \\
\hline
\end{tabular}

The amount of $\mathrm{HCl}$ transported grows with its increasing content in the feeds both with Ru(III) and without metal ions. Significant co-extraction of $\mathrm{HCl}$ and $\mathrm{Ru}(\mathrm{III})$, observed at high concentration of the acid (5 M), explains decrease in the value of $\mathrm{D}_{\mathrm{Ru}(\mathrm{III})}$ with increasing $\mathrm{HCl}$ content in the feed. However, the content of $\mathrm{HCl}$ after the extraction from $5 \mathrm{M}$ feed exceeds significantly the IL concentration which cannot be assigned only to reaction of $\mathrm{HCl}$ extraction with IL as it was proposed by Góralska et al. (2007) for quaternary ammonium salts:

$\mathrm{R}_{3} \mathrm{NHCl}_{(\text {org })}+\mathrm{H}_{(\mathrm{aq})}^{+}+\mathrm{Cl}_{(\mathrm{aq})}^{-} \Leftrightarrow \mathrm{R}_{3} \mathrm{NH}_{2} \mathrm{Cl}_{2 \text { (org) }}$

As Martak and Schlosser (2006, 2016) emphasized, phosphonium ILs are prone to form reverse micelles in extraction systems. Thus, excessive $\mathrm{HCl}$ can be transported to the organic phase incorporated into reverse micelles. It is clearly visible for IL 167, which extracts high amount of $\mathrm{HCl}$ even in the presence of $\mathrm{Ru}(\mathrm{III})$ and forms emulsions as a result of higher hydrophilicity of the phosphonium cation compared to Cyphos IL 101.

Chemistry of $\mathrm{Ru}(\mathrm{III})$ species in chloride solutions is complex. However, the literature data (Afzaletdinova et al. 2007; Orysyk et al. 2010) show that at $\mathrm{Cl}^{-}$concentration below $6 \mathrm{M}$, apart from $\left[\mathrm{Ru}\left(\mathrm{H}_{2} \mathrm{O}\right) \mathrm{Cl}_{5}\right]^{2-}$, the solution contains also $\left[\mathrm{Ru}\left(\mathrm{H}_{2} \mathrm{O}\right)_{2} \mathrm{Cl}_{4}\right]^{-}$. Moreover, some amounts of $\left[\mathrm{Ru}\left(\mathrm{H}_{2} \mathrm{O}\right)_{3} \mathrm{Cl}_{3}\right]$, cis- and trans- $\left[\mathrm{Ru}\left(\mathrm{H}_{2} \mathrm{O}\right)_{4} \mathrm{Cl}_{2}\right]^{+}$, and $\left[\mathrm{Ru}\left(\mathrm{H}_{2} \mathrm{O}\right)_{5} \mathrm{Cl}\right]^{2+}$ ions can be present. For anionic chlorocomplexes of $\mathrm{Ru}(\mathrm{III})$, the mechanism of extraction with Cyphos ILs is similar to that one proposed by Cieszyńska and Wiśniewski $(2012,2012)$ for Pd(II) extraction. Phosphonium chlorides, similarly to quaternary ammonium salts (Panigrahi et al. 2014), can extract trivalent metal chlorocomplexes according to anion-exchange reactions:

$\mathrm{RuCl}_{5(\mathrm{aq})}^{2-}+2 \mathrm{R}_{3} \mathrm{R}^{\prime} \mathrm{PCl}_{(\mathrm{org})} \Leftrightarrow\left(\mathrm{R}_{3} \mathrm{R}^{\prime} \mathrm{P}\right)_{2} \mathrm{RuCl}_{5(\mathrm{org})}+2 \mathrm{Cl}_{(\mathrm{aq})}^{-}$
$\mathrm{RuCl}_{4(\mathrm{aq})}^{-}+\mathrm{R}_{3} \mathrm{R}^{\prime} \mathrm{PCl}_{(\mathrm{org})} \Leftrightarrow\left(\mathrm{R}_{3} \mathrm{R}^{\prime} \mathrm{P}\right) \mathrm{RuCl}_{4(\mathrm{org})}+\mathrm{Cl}_{(\mathrm{aq})}^{-}$

Moreover, as Cyphos IL 104 consists of bis(2,4,4trimethylpentyl)phosphinate (originating from the wellknown acidic extractant Cyanex 272) and is proven to form the organophosphoric acid in the organic phase during extraction of Pd(II) (Cieszyńska and Wiśniewski 2010, 2012) the extraction of $\mathrm{Ru}(\mathrm{III})$ is likely to run as follows:

$\mathrm{H}_{(\mathrm{aq})}^{+}+\mathrm{RuCl}_{4(\mathrm{aq})}^{-}+\mathrm{R}_{3} \mathrm{R}^{\prime} \mathrm{PCl}_{(\mathrm{org})}$

$\Leftrightarrow\left(\mathrm{R}_{3} \mathrm{R}^{\prime} \mathrm{P}\right) \mathrm{RuCl}_{4(\text { org })}+\mathrm{HA}_{(\text {org })}$

where A stands for bis(2,4,4-trimethylpentyl)phosphinate anion, subscripts (org) and (aq) denote the organic and the aqueous phases, respectively.

\section{Stripping of Ru(III) from the loaded organic phases}

The organic phases loaded with $\mathrm{Ru}(\mathrm{III})$, as a result of extraction from 0.1 to $5 \mathrm{M} \mathrm{HCl}$, were stripped with solution of $0.1 \mathrm{M}$ thiourea in $0.5 \mathrm{M} \mathrm{HCl}$. The results for stripping of $\mathrm{Ru}(\mathrm{III})$ are presented in Table 4.

About $100-135 \mathrm{mg} \mathrm{dm}^{-3}$ of $\mathrm{Ru}(\mathrm{III})$ is extracted to the organic phase after $20 \mathrm{~min}$ of extraction from feeds containing $0.1-3 \mathrm{M} \mathrm{HCl}$. When the feed contains $5 \mathrm{M} \mathrm{HCl}$ only $40-48 \mathrm{mg} \mathrm{dm}^{-3}$ of $\mathrm{Ru}(\mathrm{III})$ is transported to the organic phase after extraction. $\mathrm{Ru}(\mathrm{III})$ stripping with $0.1 \mathrm{M}$ thiourea in $0.5 \mathrm{M} \mathrm{HCl}$ is very efficient from all ILs loaded with $\mathrm{Ru}(\mathrm{III})$ at low content of $\mathrm{HCl}$. Stripping efficiency of $\mathrm{Ru}(\mathrm{III})$ from the organic phase equals about $90 \%$.

\section{Influence of shaking time on extraction of Ru(III) and $R h(I I I)$ from their mixture}

An important issue for separation processes is the possibility to recover selectively some required species from 
Table 4 Percentage stripping of Ru(III) from the loaded organic phases containing $5 \times 10^{-3}$ M Cyphos IL 101, IL 104 or IL 167

\begin{tabular}{|c|c|c|c|c|c|c|c|c|c|}
\hline \multirow[t]{2}{*}{$\mathrm{HCl}$ in feed/M } & \multicolumn{3}{|c|}{ Cyphos IL 101} & \multicolumn{3}{|c|}{ Cyphos IL 104} & \multicolumn{3}{|c|}{ Cyphos IL 167} \\
\hline & $\begin{array}{l}C_{\mathrm{org}} / \\
\left(\mathrm{mg} \mathrm{dm}^{-3}\right)\end{array}$ & $\begin{array}{l}C_{\mathrm{aq}} / \\
\left(\mathrm{mg} \mathrm{dm}^{-3}\right)\end{array}$ & $R / \%$ & $\begin{array}{l}C_{\mathrm{org}} / \\
\left(\mathrm{mg} \mathrm{dm}^{-3}\right)\end{array}$ & $\begin{array}{l}C_{\mathrm{aq}} / \\
\left(\mathrm{mg} \mathrm{dm}^{-3}\right)\end{array}$ & $R / \%$ & $\begin{array}{l}C_{\mathrm{org}} / \\
\left(\mathrm{mg} \mathrm{dm}^{-3}\right)\end{array}$ & $\begin{array}{l}C_{\mathrm{aq}} / \\
\left(\mathrm{mg} \mathrm{dm}{ }^{-3}\right)\end{array}$ & $R / \%$ \\
\hline 0.1 & 107.0 & 100.0 & 93.5 & 105.8 & 91.8 & 86.8 & 129.9 & 119.0 & 91.6 \\
\hline 1 & 119.3 & 114.2 & 95.7 & 116.3 & 75.7 & 65.1 & 135.9 & 116.5 & 85.7 \\
\hline 3 & 128.7 & 88.4 & 68.7 & 111.3 & 84.9 & 76.3 & 130.0 & 85.9 & 66.1 \\
\hline 5 & 48.5 & 30.1 & 62.1 & 39.4 & 28.3 & 71.8 & 42.1 & 38.0 & 90.4 \\
\hline
\end{tabular}

$C_{\mathrm{org}}$ - concentration of $\mathrm{Ru}(\mathrm{III})$ in the organic phase after extraction, $\mathrm{C}_{\mathrm{aq}}$ - concentration of $\mathrm{Ru}(\mathrm{III})$ in the stripping phase (strippant) and $R$ percentage stripping

Fig. 1 Effect of shaking time on the extraction of $\mathbf{a} \mathrm{Ru}(\mathrm{III})$ and $\mathbf{b} \mathrm{Rh}(\mathrm{III})$ from the mixture of these metal ions (Organic phase: $5 \times 10^{-3} \mathrm{M}$ (filled square) IL 101; (filled circle) IL 104; (filled triangle) IL 167 in toluene)

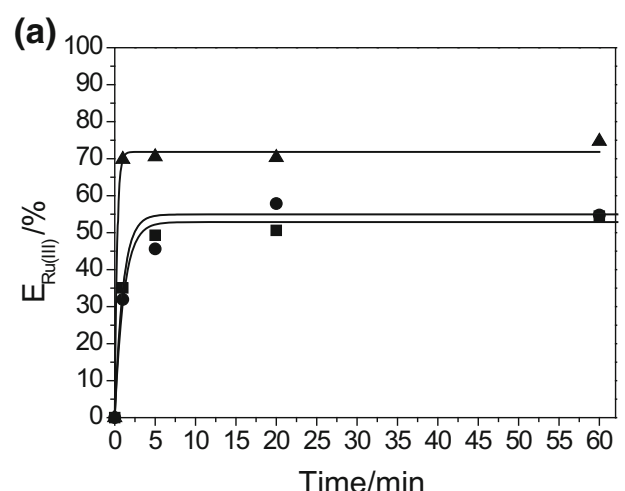

(b)

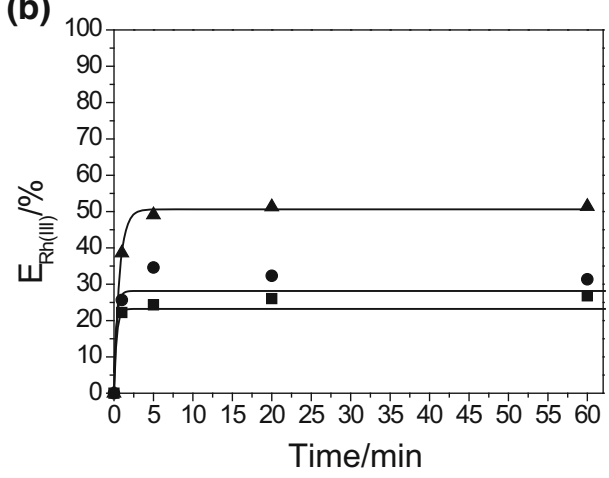

their mixtures. In this paper, separation of $\mathrm{Ru}(\mathrm{III})$ from $\mathrm{Rh}$ (III) using one of three ionic liquids as extractant was studied. The feed contained mixture of $\mathrm{Ru}(\mathrm{III})$ and $\mathrm{Rh}(\mathrm{III})$ : $1.7 \times 10^{-3} \mathrm{M} \mathrm{Ru}(\mathrm{III})$ and $0.5 \times 10^{-3} \mathrm{M} \mathrm{Rh}$ (III) in $2.5 \mathrm{M}$ $\mathrm{HCl}$ with $2.9 \mathrm{M} \mathrm{NaCl}$.

At first, for the mixtures of $\mathrm{Ru}(\mathrm{III})$ and $\mathrm{Rh}(\mathrm{III})$, an effect of contact time of both phases (the aqueous and the organic) on the extraction of metal ions from their mixture was investigated and the results are shown in Fig. 1.

As it can be seen from Fig. 1, the extraction equilibrium for both $\mathrm{Ru}(\mathrm{III})$ and $\mathrm{Rh}(\mathrm{III})$ is reached after $20 \mathrm{~min}$. The most effective extractant for $\mathrm{Ru}(\mathrm{III})$ from mixture of the metal ions is Cyphos IL 167; extraction efficiency of $\mathrm{Ru}(\mathrm{III})$ is equal to about $70 \%$. Extraction efficiency of $\mathrm{Rh}$ (III) is small regardless of the type of the extractant and amounts to about $50 \%$. The extraction efficiency of $\mathrm{Ru}$ (III) and $\mathrm{Rh}(\mathrm{III})$ decreases in the following order: Cyphos IL 167 > Cyphos IL 104 > Cyphos IL 101.

\section{Influence of Cyphos IL concentration on extraction of $R u(I I I)$ and $R h(I I I)$ from their mixture}

For model studies, two-component solutions were prepared by mixing one-component feeds and raffinates from our previous studies to investigate the possibility of selective separation of $\mathrm{Ru}(\mathrm{III})$ from $\mathrm{Rh}(\mathrm{III})$. Generally, concentration of $\mathrm{HCl}$ in the PGM leaching solutions reported by different authors changes in the range from 1 even up to $12 \mathrm{M} \mathrm{HCl}$. These are solutions after leaching of PGM concentrates (Bernardis et al. 2005; Jha et al. 2014) or secondary sources such as automotive and industrial catalytic converters (Jimenez de Aberasturi et al. 2011; Suoranta et al. 2015). The model solutions used by us were the mixture of various aqueous solutions of $\mathrm{HCl}$ with concentration close to $3 \mathrm{M}$.

An effect of ILs' concentration in the organic phase on extraction of $\mathrm{Ru}(\mathrm{III})$ and $\mathrm{Rh}(\mathrm{III})$ from a mixture of these metal ions is presented in Fig. 2.

On the basis of $D$ values, the extraction selectivity of $\mathrm{Ru}$ (III) in the presence of $\mathrm{Rh}(\mathrm{III})$ with Cyphos IL 101, Cyphos IL 104 or Cyphos IL 167 was calculated as the ratio of $D_{\mathrm{Ru}(\mathrm{III})}$ and $D_{\mathrm{Rh}(\mathrm{III})}$. The results are shown in Table 5.

It is obvious that all ILs used are selective extractants for $\mathrm{Ru}(\mathrm{III})$ recovery from its mixture with $\mathrm{Rh}(\mathrm{III})$. Moreover, Cyphos IL 104 is a more efficient extractant of $\mathrm{Ru}$ (III) from mixture than Cyphos IL 101 (Fig. 2a; Table 5). The values of $\mathrm{Ru}(\mathrm{III})$ distribution ratio $\left(D_{\mathrm{Ru}(\mathrm{III})}\right)$ are high, while $\mathrm{Rh}(\mathrm{III})$ extraction with all IL-organic phases is poor. In addition, an increase in IL content in the organic phase causes a rise in $D_{\mathrm{Ru}(\mathrm{III})}$ from about 2.2 to 4.2 (IL 101), 2.8 to 4.6 (IL 104) and 1.9 to 3.4 (IL 167) 
Fig. 2 Effect of ILs concentration in the organic phase on extraction of $\mathbf{a} \mathrm{Ru}(\mathrm{III})$ and $\mathbf{b} \mathrm{Rh}(\mathrm{III})$ from the mixture of these metal ions (Organic phase: (filled square) IL 101; (filled circle) IL 104; (filled triangle) IL 167 in toluene)

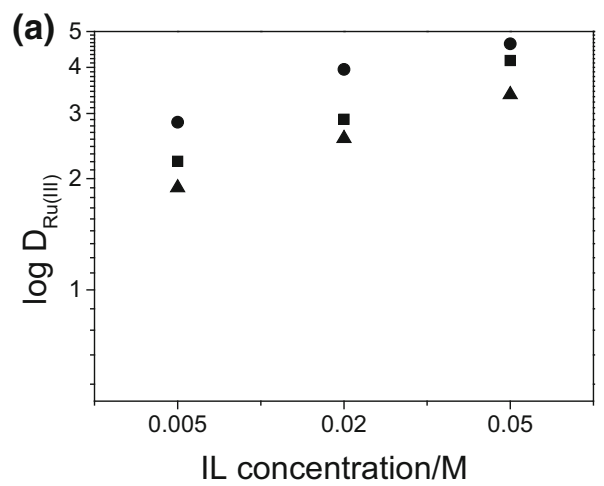

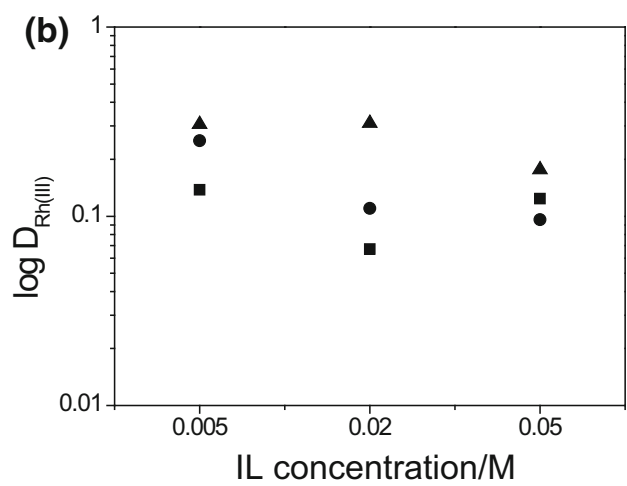

Table 5 Extraction selectivity of the $\mathrm{Ru}(\mathrm{III})$ in the presence of Rh(III) with Cyphos IL 101, Cyphos IL 104 or Cyphos IL 167

\begin{tabular}{llll}
\hline IL/M & \multicolumn{2}{l}{$\mathrm{S}_{\mathrm{Ru}(\mathrm{III}) / \mathrm{Rh}(\mathrm{III})}$} & \\
\cline { 2 - 4 } & Cyphos IL 101 & Cyphos IL 104 & Cyphos IL 167 \\
\hline $5 \times 10^{-3}$ & 16.4 & 43.0 & 33.6 \\
$2 \times 10^{-2}$ & 11.3 & 35.9 & 48.1 \\
$5 \times 10^{-2}$ & 6.2 & 8.3 & 19.2 \\
\hline
\end{tabular}

(Fig. 2a), while $D_{\text {Rh(III) }}$ does not exceed 0.35 (Fig. 2b) and is not affected by the concentration of IL in the organic phase. Hence, the best selectivity of Ru(III) extraction is obtained with $5 \times 10^{-3}$ and $2 \times 10^{-2}$ M Cyphos IL 104 and IL 167.

\section{Conclusions}

The results presented in the paper indicate that Cyphos IL 167 is the best extractant for extraction of $\mathrm{Ru}(\mathrm{III})$ from single-metal feeds. Distribution ratio of $\mathrm{Ru}(\mathrm{III})$ is equal to almost 3 for $1 \mathrm{M} \mathrm{HCl}$ in the feed; however, the problems with emulsion formation eliminate this IL from application as extractant.

With increasing concentration of $\mathrm{HCl}$ in the feed, extraction of $\mathrm{HCl}$ into the organic phase also increases. Coextraction of $\mathrm{HCl}$ to the organic phase may be the reason for the decrease in $D_{\mathrm{Ru}(\mathrm{III})}$ values. $D_{\mathrm{Ru}(\mathrm{III})}$ are the smallest for all ILs when the concentration of $\mathrm{HCl}$ in the feed is $5 \mathrm{M}$. An excessive transport of $\mathrm{HCl}$ in the relation to IL content in the organic phase can be assigned to formation of reverse micelles in the organic phase containing phosphonium ILs.

Stripping efficiency of $\mathrm{Ru}(\mathrm{III})$ from the organic phases is equal to about $90 \%$, when the organic phases were loaded with $\mathrm{Ru}(\mathrm{III})$ from the feed solutions containing small amounts of $\mathrm{HCl}$.
The presence of $\mathrm{NaCl}$ in the feed phase (mixture of $\mathrm{Ru}(\mathrm{III})$ and $\mathrm{Rh}(\mathrm{III})$ ) facilitates the phase separation as a result of the salting out effect. Additionally, it also ensures content of chloride ions high enough to form anionic chlorocomplexes of $\mathrm{Ru}(\mathrm{III})$.

All ILs studied are very selective for $\mathrm{Ru}(\mathrm{III})$ extraction in the presence of $\mathrm{Rh}(\mathrm{III})$. Also it is noteworthy that Cyphos IL 104 is the best extractant for $\mathrm{Ru}(\mathrm{III})$ from mixture of $\mathrm{Ru}(\mathrm{III})-\mathrm{Rh}(\mathrm{III})$. On the contrary, $\mathrm{Rh}(\mathrm{III})$ extraction from mixture of $\mathrm{Ru}(\mathrm{III})-\mathrm{Rh}(\mathrm{III})$ is very low, distribution ratio $\mathrm{D}_{\mathrm{Rh}(\mathrm{III})}$ does not exceed 0.35 . Thus, the best selectivity of $\mathrm{Ru}(\mathrm{III})$ extraction is obtained with $5 \times 10^{-3}$ and $2 \times 10^{-2}$ M Cyphos IL 104 and IL 167 . $\mathrm{Rh}(\mathrm{III})$ extraction does not depend on the concentration of the IL used.

Acknowledgements The authors would like to thank Eng. Anna Kowalska and Eng. Marta Tarnowska for their help in research for ruthenium(III). The research was supported by the 03/32/DS-PB/0701 Grant.

Open Access This article is distributed under the terms of the Creative Commons Attribution 4.0 International License (http://crea tivecommons.org/licenses/by/4.0/), which permits unrestricted use, distribution, and reproduction in any medium, provided you give appropriate credit to the original author(s) and the source, provide a link to the Creative Commons license, and indicate if changes were made.

\section{References}

Abbott AP, Frisch G, Hartley J, Ryder KS (2011) Processing of metals and metal oxides using ionic liquids. Green Chem 13:471-481. doi:10.1039/c0gc00716a

Afzaletdinova NG, Ryamova LM, Murinov YI (2007) Extraction of chlororuthenium(III) complexes by triazole derivatives from hydrochloric acid solutions. Russ J Inorg Chem 52:800-805. doi: 10.1134/S0036023607050269

Alguacil FJ, Alonso M, Lopez FA, Lopez-Delgado A (2010) Pseudoemulsion membrane strip dispersion (PEMSD) pertraction of chromium(VI) using CYPHOS IL101 ionic liquid as carrier. Environ Sci Technol 44:7504-7508 
Baczyńska M, Regel-Rosocka M (2013) Phosphonium ionic liquids as carriers of metal ions. Przemysł Chemiczny 92(9):1574-1576 (in Polish)

Baczyńska M, Rzelewska M, Regel-Rosocka M, Wiśniewski M (2016) Transport of iron ions from chloride solutions using cellulose triacetate matrix inclusion membranes with an ionic liquid carrier. Chem Pap 70(2):172-179. doi:10.1515/chempap2015-0198

Bernardis FL, Grant RA, Sherrington DC (2005) A review of methods of separation of the platinum-group metals through their chlorocomplexes. React Funct Polym 65:205-217. doi:10.1016/j. reactfunctpolym.2005.05.011

Billard I (2013) Ionic liquids: new hopes for efficient lanthanide/ actinide extraction and separation? handbook on the physics and chemistry of rare earths, Vol. 43, Elsevier, Amsterdam. doi:10. 1016/B978-0-444-59536-2.00003-9

Cieszyńska A, Wiśniewski M (2010) Extraction of palladium(II) from chloride solutions with $\mathrm{Cyphos}^{\circledR} \mathrm{IL}$ 101/toluene mixtures as novel extractant. Sep Purif Technol 73:202-207. doi:10.1016/j. seppur.2010.04.001

Cieszyńska A, Wiśniewski M (2012) Extractive recovery of palladium(II) from hydrochloric acid solutions with Cyphos IL 104. Hydrometallurgy 113-114:79-85. doi:10.1016/j.hydromet.2011. 12.006

de San Rodríguez, Miguel E, Vital X, de Gyves J (2014) Cr(VI) transport via a supported ionic liquid membrane containing CYPHOS IL101 as carrier: system analysis and optimization through experimental design strategies. J Hazard Mater 273:253-262. doi:10.1016/j.jhazmat.2014.03.052

Dragulovic S, Ljubomirovic Z, Stanojevic Simsic Z, Conic V, Dimitrijevic S, Cvetkovski V, Trujic V (2011) Recovery of rhodium from secondary raw materials for usage in electronic devices. Journal of Optoelectronics and Advanced Materials 5(12):1370-1375

Drušković V, Vojković V, Antonić T (2005) Extraction of ruthenium and its separation from rhodium and palladium with 4-pyridone derivatives. Croat Chem Acta 78:617-626

Fornalczyk A, Saternus M (2007) Recycling of spent auto catalyst. Rudy i Metale Nieżelazne, R 52(6):326-332 (in Polish)

Góralska E, Coll MT, Fortuny A, Kedari CS, Sastre AM (2007) Studies on the selective separation of $\operatorname{Ir}(\mathrm{IV}), \mathrm{Ru}(\mathrm{III})$ and $\mathrm{Rh}(\mathrm{III})$ from chloride solutions using Alamine 336 in kerosene. Solv Extr Ion Exchange 25:65-77. doi:10.1080/07366290601067820

Guibal E, Campos Gavilan K, Bunio P, Vincent T, Trochimczuk A (2008) CYPHOS IL 101(tetradecyl(trihexyl)phosphonium chloride) immobilized in biopolymer capsules for $\mathrm{Hg}$ (II) recovery from $\mathrm{HCl}$ solutions. Sep Sci Technol 43:2406-2433. doi:10. 1080/01496390802118970

Guo L, Liu Y, Zhang C, Chen J (2011) Preparation of PVDF-based polymer inclusion membrane using ionic liquid plasticizer and Cyphos IL 104 carrier for Cr(VI) transport. J Membr Sci. doi:10. 1016/j.memsci.2011.02.014

IUPAC (2014). Compendium of Chemical Terminology, available at: http://goldbook.iupac.org/PDF/D01817.pdf. Accessed 20 Oct 2016. doi:10.1351/goldbook.D01817

Jha MK, Gupta D, Lee JC, Kumar V, Jeong J (2014) Solvent extraction of platinum using amine based extractants in different solutions: a review. Hydrometallurgy 142:60-69. doi:10.1016/j. hydromet.2013.11.009

Jimenez de Aberasturi D, Pinedo R, Ruiz de Larramendi I, Ruiz de Larramendi JI, Rojo T (2011) Recovery by hydrometallurgical extraction of the platinum-group metals from car catalytic converters. Miner Eng 24:505-513. doi:10.1016/j.mineng.2010. 12.009

Kogelnig D, Regelsberger A, Stojanovic A, Jirsa F, Krachler R, Keppler BK (2011) A polymer inclusion membrane based on the ionic liquid trihexyl(tetradecyl)phosphonium chloride and PVC for solid-liquid extraction of $\mathrm{Zn}$ (II) from hydrochloric acid solution. Monatsh Chem 142:769-772. doi:10.1007/s00706-0110530-6

Kuchekar SR, Shelar YS, Bhor RJ, Anuse MA, Naval RM (2015) Separation and spectrophotometric determination of osmium(IV) and ruthenium(III) with O-methoxyphenyl thiourea as chromogenic ligand: sequential separation of osmium(IV), ruthenium(III) and platinum(IV). Sep Sci Technol 50:1190-1201. doi:10.1080/01496395.2014.983245

Kumari A, Sinha MK, Sahu SK, Pandey BD (2016) Solvent extraction and separation of trivalent lanthanides using Cyphos IL 104, a novel phosphonium ionic liquid as extractant. Solv Extr Ion Exchange 34(5):469-484. doi:10.1080/07366299.2016.1207459

Leyma R, Platzer S, Jirsa F, Kandioller W, Krachler R, Keppler BK (2016) Novel thiosalicylate-based ionic liquids for heavy metal extractions. J Hazard Mater 314:164-171. doi:10.1016/j.jhazmat. 2016.04.038

Marták J, Schlosser Š (2004) Ionic liquids in pertraction and extraction of organic acids. In: 19th Symposium Ars Separatoria, Zloty Potok, University of Technology and Agriculture in Bydgoszcz, Poland

Marták J, Schlosser Š (2006) Phosphonium ionic liquids as new, reactive extractants of lactic acid. Chem Pap 60(5):395-398. doi:10.2478/s11696-006-0072-2

Marták J, Schlosser Š (2016) New mechanism and model of butyric acid extraction by phosphonium ionic liquid. J Chem Eng Data 61:2979-2996. doi:10.1021/acs.jced.5b01082

Matthey J., About PGM- Production from http://www.platinum. matthey.com/about-pgm/production. Accessed 10 June 2016

Navarro R, Saucedo I, Gallardo V, Guibal E (2016) Fe(III) recovery from $\mathrm{HCl}$ solutions using Amberlite XAD-7 resin impregnated with a tetraalkyl phosphonium ionic liquid. Can J Chem Eng 94:107-116. doi:10.1002/cjce.22356

Orysyk SI, Rybachuk LN, Pekhnyo VI, Korduban AM, Buslaeva TM (2010) The formation of $\mathrm{Ru}(\mathrm{III})$ and $\mathrm{Rh}(\mathrm{III})$ chloro aqua complexes and tautomeric forms of carboxylic acid benzoylhydrazones for the synthesis of new coordination compounds promising for the practical use. Russ J Inorg Chem 55:1075-1082. doi:10.1134/S0036023610070132

Panigrahi S, Dash T, Nathsarma KC, Sarangi K (2014) Extraction of ruthenium using both tertiary and quaternary amine from chloride media. Sep Sci Technol 49:545-552. doi:10.1080/ 01496395.2013.850509

Papaiconomou N, Svecova L, Bonnaud C, Cathelin L, Billard I, Chainet E (2015) Possibilities and limitations in separating $\mathrm{Pt}(\mathrm{IV})$ from $\mathrm{Pd}(\mathrm{II})$ combining imidazolium and phosphonium ionic liquids. Dalton Trans 44:20131-20138. doi:10.1039/ c5dt03791c

Pośpiech B (2012) Studies on platinum recovery from solutions after leaching of spent catalysts by solvent extraction. Physicochem Probl Miner Process 48(1):239-246

Pośpiech B (2015) Application of phosphonium ionic liquids as ion carriers in polymer inclusion membranes (PIMs) for separation of cadmium(II) and copper(II) from aqueous solutions. J Solut Chem 44:2431-2447. doi:10.1007/s10953-015-0413-2

Regel-Rosocka, M., \& Materna, K. (2014). Ionic liquids for separation of metal ions and organic compounds from aqueous solutions. In: Pérez De Los Ríos A, Hernández Fernández FJ (eds.) Ionic Liquids in Separation Technology, Elsevier, Netherlands-Oxford-Waltham, p 153-188

Regel-Rosocka M, Cieszyńska K, Wiśniewski M (2006) Extraction of zinc(II) with selected phosphonium ionic liquids. Przemysł Chemiczny 85:651-654

Regel-Rosocka M, Nowak Ł, Wiśniewski M (2012) Removal of zinc(II) and iron from chloride solutions with phosphonium ionic 
liquids. Sep Purif Technol 97:158-163. doi:10.1016/j.seppur. 2012.01.035

Regel-Rosocka M, Rzelewska M, Baczyńska M, Wiśniewski M (2015) Removal of palladium(II) from aqueous chloride solutions with cyphos phosphonium ionic liquids as metal ion carriers for liquid-liquid extraction and transport across polymer inclusion membranes. Physicochem Probl Miner Process 51(2):621-631. doi:10.5277/ppmp150221

Rzelewska M, Baczyńska M, Regel-Rosocka M, Wiśniewski M (2016) Trihexyl(tetradecyl)phosphonium bromide as extractant for $\mathrm{Rh}(\mathrm{III}), \mathrm{Ru}(\mathrm{III})$ and $\mathrm{Pt}(\mathrm{IV})$ from chloride solutions. Chem Pap 70(4):454-460. doi:10.1515/chempap-2015-0223

Sun P, Lee M (2013) Recovery of platinum from spent petroleum catalysts by a hydrometallurgical method. Korean J Metals Mater 51(12):873-881. doi:10.3365/KJMM.2013.51.12.873
Suoranta T, Zugazua O, Niemelä M, Perämäki P (2015) Recovery of palladium, platinum, rhodium and ruthenium from catalyst materials using microwave-assisted leaching and cloud point extraction. Hydrometallurgy 154:56-62. doi:10.1016/j.hydro met.2015.03.014

Vander Hoogerstraete T, Wellens S, Verachtert K, Binnemans K (2013) Removal of transition metals from rare earths by solvent extraction with an undiluted phosphonium ionic liquid: separations relevant to rare-earth magnet recycling. Green Chem 15:919-927. doi: 10.1039/c3gc40198g

Vincent T, Parodi A, Guibal E (2008) Immobilization of Cyphos IL101 in biopolymer capsules for the synthesis of Pd sorbents. React Funct Polym 68:1159-1169. doi:10.1016/j.reactfunctpo lym.2008.04.001 